\title{
MODEL PENDIDIKAN KARAKTER KEWIRAUSAHAAN MELALUI UNIT PRODUKSI DAN JASA DI SMKN 2 PENGASIH
}

\author{
Nuryadin Eko Raharjo \\ Jurusan Pendidikan Teknik Sipil dan Perencanaan \\ Fakultas Teknik Universitas Negeri Yogyakarta \\ Email: nuryadin_er@uny.ac.id
}

\begin{abstract}
The objectives of this study were to determine the entrepreneurial character education model through unitof productionandservicesof Engineering Construction Wood in SMKN 2 Pengasih. Research conducted using the phenomenological qualitative approach in SMKN 2 Pengasih concluded as follows. (1) The strategy used in character education in entrepreneurship through UPJ TKKY SMKN Pengasih includes: examples, learning, empowerment, habituation, strengthening, and assessment. (2) The character of entrepreneurship developed by UPJ TKKY consist of: (a) mindset includes: creative, innovative, and realistic, (b) heartset include: risk-taking, honesty, responsibility, curiosity, unyielding, independent, and strong motivation for success, (c) actionset include: hard work, action-oriented, communicative, teamwork, and discipline. (3) Model of entrepreneurial character education through UPJ TKKY in SMKN 2 Pengasih conducted through curricular activities and through the production process UPJ.
\end{abstract}

Keywords: model of entrepreneurialcharacter education, SMK,UPJ.

\begin{abstract}
ABSTRAK
Penelitian ini bertujuan untuk mengetahui model pendidikan karakter kewirausahaan yang dilakukan melalui UPJ Teknik Konstruksi Kayu (TKKY) di SMKN 2 Pengasih.Penelitian yang dilaksanakan dengan menggunakan pendekatan kualitatif fenomenologisbertempat di SMKN 2 Pengasih ini menyimpulkan sebagai berikut. (1) Strategi yang digunakan dalam pendidikan karakter kewirausahaan melalui UPJ TKKY di SMKN 2 Pengasih meliputi: keteladanan, pembelajaran, pemberdayaan, pembiasaan, penguatan, dan penilaian. (2) Karakter kewirausahaan yang dikembangkan melalui UPJ TKKY terbagi menjadi: (a) ranah pola pikir (mindset)meliputi: kreatif, inovatif, dan realistis, (b) ranah pola rasa (heartset)meliputi: berani mengambil risiko, jujur, tanggung jawab, rasa ingin tahu, pantang menyerah, mandiri, dan motivasi kuat untuk sukses, (c) ranah pola tindakan (actionset)meliputi: kerja keras, berorientasi pada tindakan, komunikatif, kerja sama, dan disiplin. (3) Model pendidikan karakter kewirausahaan melalui UPJ TKKY di SMKN 2 Pengasih dilakukan melalui kegiatan kurikuler dan melalui kegiatan proses produksi UPJ.
\end{abstract}

Kata kunci: model pendidikan karakter kewirausahaan, SMK, UPJ.

\section{PENDAHULUAN}

Pengembangan SMK diarahkan untuk dapat menciptakan lulusan yang mampu untuk berwirausaha, bekerja maupun melanjutkan ke pendidikan yang lebih tinggi. Hal ini mengindikasikan bahwa fokus pengembangan SMK tidak hanya untuk menghasilkan tenaga kerja, terlapi juga terletak pada pengembangan kewirausahaan. Akbar (2009:1) menjelaskan bahwa dari penelitian di Harvard University disimpulkan bahwa kesuksesan seseorang tidak ditentukan semata-mata oleh pengetahuan dan kemampuan teknis (hard 
skill) yang lebih bersifat mengembangkan intelligence quotient (IQ), tetapi lebih oleh kemampuan mengelola diri dan orang lain (soft skill). Penelitian ini mengungkapkan, kesuksesan hanya ditentukan sekitar $20 \%$ oleh hard skills dan sisanya $80 \%$ oleh soft skills. Hasil penelitian tersebut sesuai dengan pendapat Golemen (2006:44) yang menyatakan bahwa keberhasilan seseorang di masyarakat, 80\% akan dipengaruhi oleh kecerdasan emosi (EQ) dan 20\% dipengaruhi oleh kecerdasan otak (IQ).Hasil penelitian tersebut mengisyaratkan bahwa pengembangan kewirausahaan di SMK harus dilakukan secara komprehensif, tidak hanya dalam hard skills saja tetapi justru lebih ditekankan pada pengembangan soft skills di bidang kewirausahaan. Pengembangan soft skills kewirausahaan akan banyak berkaitan dengan pengembangan karakter kewirausahaan.

Secara yuridis, pengembangan karakter kewirausahaan juga sesuai dengan Instruksi Presiden No. 4 Tahun 1995 tentang Gerakan Nasional Memasyarakatkan dan Membudayakan Kewirausahaan. Melalui gerakan ini diharapkan budaya kewirausahaan akan menjadi bagian dari etos kerja dari masyarakat, termasuk warga SMK sehingga dapat melahirkan wirausaha baru yang handal, tangguh, dan mandiri.Selain itu Presiden RI melalui Pidato Presiden pada Nasional Summit Tahun 2010 mengamanatkan perlunya penggalakkan jiwa kewirausahaan dan metodologi pendidikan yg lebih mengembangkan kewirausahaan (Usman, 2010:8)

Secara filosofis, pendidikan karakter sebenarnya sudah ditanamkan oleh Ki Hajar Dewantara. Di dalam konsep pendidikannya, beliau berpendapat bahwa pendidikan adalah daya upaya untuk memajukan bertumbuhnya budi pekerti (kekuatan batin, karakter), pikiran (intelect) dan tubuh anak. Komponen-komponen budi pekerti, pikiran, dan tubuh anak tidak boleh dipisah-pisahkan agar dapat memajukan kesempurnaan hidup anak-anak. Dengan demikian dapat dimaknai bahwa menurut Ki Hajar Dewantara pendidikan karakter merupakan bagian integral yang sangatpenting dalam pendidikan (Samani \& Hariyanto, 2011:33). Karakter kewirausahaan merupakan karakter seorang wirausaha yang diimplementasikan dalam proses kewirausahaan. Menurut Dharma (2009:14) dan International Training CentreILO (2005:7), karakter kewirausahaan terbagi menjadi tiga dimensi, yaitu: mindset, heartset dan actionset.

Untuk menumbuhkan karakter wirausaha diperlukan suasana belajar dan berlatih menjalankan usaha menjadi iklim yang berkembang di sekolah. Siswa dan guru dapat mengembangkan berbagai aktivitas usaha dalam menanggapi berbagai peluang yang ada di sekitar sekolah. Dengan cara ini siswa akan lebih siap menghadapi tantangan dan peluang usaha ketika mereka telah tamat kelak. Kesiapan tersebut dapat tercipta karena selain kompetensi produktif mereka semakin tajam, pengalaman usaha juga telah terasah (Dharma, 2007:2).

Selanjutnya Dharma(2007:99)menjelaskan bahwa unit produksi dan jasa SMK, idealnya dapat menjadi wadah dimana siswa tidak hanya mempertajam kompetensinya, tetapi juga belajar tentang mengembangkan kemampuan berwirausaha. Karena melalui unit produksi dan jasa SMK para siswa belajar berbagai pengalaman mengoperasikan usaha. Bagaimana mereka belajar tentang selera pelanggan, kelayakan produk, administrasi keuangan, pemasaran, bernegosiasi, pelayanan terhadap pelanggan, dan masih banyak lagi. Dengan demikian unit produksi dan jasa SMK sangat memungkinkan dijadikan sebagai wadah dalam menumbuhkan karakter kewirausahaan warga sekolah.

Unit produksi dan jasa Teknik Konstruksi Kayu (UPJ TKKY) di SMKN 2 Pengasih merupakan salah satu unit produksi dan jasa di dalam SMK Kelompok Teknologi dan Industri yang dapat berjalan dengan baik untuk wilayah di Propinsi Daerah Istimewa Yogyakarta. Dalam UPJ TKKY siswa dilibatkan sebagai pendamping tenaga profoseional yang bekerja dalam UNJ tersebut. Berbagai produk seperti kosen pintu dan jendela, meja kursi tamu, meja kursi siswa, meja kursi guru, dan barang-barang kerajinan tangan telah diprosuksinya. Konsumen UPJ TKKY tidak hanya sebatas pada konsumen internal sekolah, tetapi juga sudah merambah ke konsumen dari masyarakat di sekitar 
sekolah. Untuk menemukan model pendidikan karakter kewirausahaan di UPJ TKKY SMKN 2 Pengasih perlu dilakukan penelitian dengan rumusan masalah sebagai berikut:

(1) Bagaimana strategi dalam pendidikan karakter kewirausahaan melalui UPJ TKKY SMKN 2 Pengasih?

(2) Karakter kewirausahaan apa sajakah yang dikembangkan di UPJ TKKY SMKN 2 Pengasih?

(3) Seperti apakah model pendidikan karakter kewirausahaan di unit produksi dan jasa TKKY SMKN 2 Pengasih?

Untuk mendefinisikan kewirausahaan dapat dilakukan dari berbagai sudut pandang seperti yang disampaikan oleh Simpeh (2011:1). Ia menjelaskan bahwa kewirausahaan dapat didefinisikan secara historis dari beberapa sudut pandang yaitu: (1) sudut pandang ekonomi, yang menguraikan faktor-faktor pendukung perilaku wirausaha, (2) sudut pandang psikologi yang memandang kewirausahaan dari karakteristik wirausaha, (3) sudut pandang sosiologi yang memandang kewirausahaan dalam konteks sosial, (4) sudut pandang antropologi yang memandang budaya kewirausahaan, (5) sudut pandang teori peluang (opportunity-based), yang menjelaskan wirausaha dalam memanfaatkan peluang, dan (6) Sudut pandang pemanfaatan sumber daya, yang menguraikan kewirausahaan dalam memanfaatkan sumberdaya yang ada.

Kewirausahaan merupakan kemampuan seseorang, baik yang berkerja di bidang bisnis maupun non bisnis dalam menciptakan sesuatu yang baru secara kreatif, inovatif,disertai dengankeberanian untuk mengambil resiko, serta melaksanakannya dengan memanfaatkan dan mengembangkan sumberdaya yang ada melalui kemampuan managerial. Adapun wirausaha adalah pelaku atau orang yang memiliki kemampuan kewirausahaan.

Dharma (2009:14) dan ILO (2005:7)menjelaskan bahwa seorang wirausaha yang sukses harus memiliki tiga kompetensi yaitu pengetahuan, keterampilan, dan sifat kewirausahaan. Kompetensi merupakan penguasaan pengetahuan, keterampilan, dan sifat. Pengetahuan adalah kumpulan informasi yang disimpan di otak dan dapat dipanggil jika dibutuhkan. Keterampilan adalah kemampuan menerapkan pengetahuan. Sifat adalah sekumpulan kualitas karakter yang membentuk kepribadian seseorang (ILO, 2005:7). Selanjutnya Dharma (2010:9) menjelaskan bahwa terdapat dua dimensi kewirausahaan yaitu: (1) dimensi kualitas dasar kewirausahaan, yang meliputi kualitas:mindset, heartset, dan actionset, serta (2) dimensi kualitas instrumental kewirausahaan, yaitu penguasaan lintas disiplin ilmu.

Pendidikan karakter adalah pendidikan yang menanamkan kebiasaan (habituation) tentang hal mana yang baik sehingga peserta didik menjadi paham (kognitif) tentang mana yang benar dan salah, mampu merasakan (afektif) nilai yang baik dan biasa melakukannya (psikomotor). Sedang pendidikan karakter kewirausahaan adalah pendidikan tentang nilai dasar yang membangun pribadi seseorang dalam proses kewirausahaan, terdiri dari mindset, heartset dan actionset, yang terbentuk baik karena pengaruh hereditas maupun pengaruh lingkungan, serta digunakan sebagai landasan untuk cara pandang, berpikir, bersikap, dan bertindak sebagai seorang wirausaha.

Sementara itu unit Produksi dan Jasa (UPJ) SMK ialah suatu proses kegiatan usaha yang dilakukan sekolah secara berkesinambungan, bersifat akademis dan bisnis dengan memberdayakan warga sekolah dan lingkungan dalam bentuk unit usaha produksi/jasa yang dikelola secara profesional (Sartono dalam Dharma, 2007:6). UPJ SMK juga merupakan suatu usaha incorporated-enterpreuneur atau suatu wadah kewirausahaan dalam suatu organisasi yang memerlukan kewenangan khusus dari pimpinan sekolah kepada pengelola untuk melakukan tugas dan tanggungjawabnya secara demokratis. Karena UPJ SMK adalah wadah kewirausahaan di sekolah maka ia harus dikelola secara akademis/bisnis dan dilembagakan dalam suatu wadah usaha. 


\section{METODE}

Penelitian tentang pendidikan karakter kewirausahaan melalui unit produksi dan jasa di SMKN 2 Pengasih ini akan dilakukan dengan menggunakan metode penelitian kualitatif naturalistik. Pendekatan ini dipilih karena dalam eksplorasi masalah karakter kewirausahaan yang melekat pada diri warga sekolah dipahami secara mendalam atas peristiwa-peristiwa dan kaitannya dalam situasi-situasi tertentu dengan cara berusaha untuk memasuki ke dalam dunia konseptual para subjek yang diteliti sedemikian rupa, sehingga diharapkan dapat dimengerti apa dan bagaimana proses internalisasi nilai kewirausahaan melalui unit produksi dan jasa dapat terjadi.

Subyek dalam penelitian ini mencakup:siswa, kepala sekolah, guru/pengelola unit produksi dan jasa, serta karyawan UPJ TKKY SMKN 2 Pengasih. Adapun yang menjadi informan kunci dalam penelitian ini terbagi menjadi informan kunci utama (primer) dan informan kunci pendukung (sekunder).

Sesuai fokus penelitian dan pendekatan yang dipilih, maka dalam pengumpulan data, teknik yang digunakan adalah observasi, wawancara dan studi dokumen.Dalam pengumpulan data, prinsip yang ditekankan dalam penelitian kualitatif yang menjadi perhatian peneliti yakni:

(a) Prinsip Emik dan Etik - prinsip pengumpulan data secara objektif dengan lebih mengutamakan sudut pandang subjek, artinya penelitian mendeskripsikan ide, gagasan pemikiran atau pemikiran-pemikiran lain berdasarkan pernyataan subyek (prinsip emik). Namun demikian untuk kasus-kasus tertentu peneliti berusaha membuat kesimpulan dengan tanpa mengabaikan esensi makna fenomena dengan mempertimbangkan pandangan orang diluar subyek penelitian (prinsip etik).

(b) Prinsip Holistik - mengacu pada pengumpulan data yang utuh, lengkap dan kontekstual.

(c) Prinsip Kekonsistenan - menyangkut konsistensi dalam hal sistem pengamatan, penentuan struktur penjelasan dan kode pengkategorian.

Secara garis besar komponen dalam analisis data mengadopsi pemikiran Miles dan Huberman (1994:12) yaitu mencakup aktivitas yang berlangsung bersamaan yakni reduksi data, penyajian data dan penarikan kesimpulan/verifikasi. Dalam penelitian ini keabsahan data tetap dijaga sehingga hasilnya dapat dipertanggungjawabkan.Beberapa standar yang diperhatikan dalam keabsahan data adalah:

\section{Standar Kredibilitas}

Untuk menjamin standar ini peneliti melakukan hal-hal berikut:

(a) Memperpanjang keterlibatan di lapangan.

(b) Melakukan observasi terus menerus dan sungguh-sungguh sehingga dapat mendalami fenomena yang ada.

(c) Melakukan triangulasi (memperhatikan metoda, isi dan proses).

(d) Mengadakan member check.

(e) Analisis Kasus Negatif.

(f) Menggunakan bahan referensi.

2. Standar Transferabilitas-Standar ini berhubungan dengan kemampuan peneliti dalam menyajikan data hasil penelitian sehingga pembaca dapat memaknai hasil penelitian tersebut sesuai dengan apa yang diharapkan oleh peneliti.

3. Standar Dependabilitas - yaitu pengecekan ketepatan peneliti dalam mengkonseptualisasikan data secara konsisten yang dilakukan oleh auditor yang independent atau pembimbing. Pengecekan dilakukan menyangkut keseluruhan aktivitas peneliti dalam melakukan penelitian.

4. Standar Konfirmabilitas - Standar konfirmabilitas (objektivitas) yaitu sejauhmana hasil penelitian dapat dibuktikan kebenarannya, sejauhmana hasil penelitian cocok dan 
sesuai dengan data yang telah dikumpulkan, dan sejauhmana kebulatan hasil penelitian tanpa mengandung unsur unsur yang bertentangan. Konfirmabilitas ini juga bisa diupayakan dengan mengkonsultasikan hasil temuan penelitian dengan pihak eksternal untuk menilai kredibilitas metode pengumpulan data, temuan dan interpretasi yang dibuat. Pihak eksternal yang dipilih adalah orang yang memahami fenomena dan independent.

\section{HASIL DAN PEMBAHASAN}

Dalam rangka mendidik agar lulusannya memiliki kompetensi sebagai seorang wirausaha, di SMKN 2 Pengasih telah dilaksanakan pendidikan karakter kewirausahaan, baik melalui proses belajar mengajar di kelas maupun di luar kelas. Salah satu kegiatan pendidikan karakter kewirausahaannya dilakukan melalui kegiatan Unit Produsi dan Jasa (UPJ) Teknik Konstruksi Kayu (TKKY) yang berlokasi di Bengkel Kayu pada Program Keahlian Teknik Konstruksi Kayu. UPJ TKKY memproduksi berbagai barang-barang dari kayu seperti: mebelair, kosen pintu jendela, daun pintu jendela dan kerajinan tangan. Personil yang terlibat didalamnya meliputi: guru, karyawan, tukang, dan siswa.

\section{StrategiPendidikan Karakter Kewirausahaan melalui UPJ TKK di SMKN 2 Pengasih}

Implementasi pendidikan karakter kewirausahaan di UPJ TKKY SMKN 2 Pengasih mengadopsi strategi dalam Desain Induk Pendidikan Karakter Kementerian Pendidikan Nasional (2010: 14-37) yang terdiri dari: (1) keteladanan, (2) pembelajaran, (3) pemberdayaan dan pembiasaan, (4) penguatan, (5) penilaian. Adapun penjelasan masing-masing strategi pendidikan karakter kewirausahaan yang dilaksanakan di UPJ TKKY SMKN 2 Pengasih sebagai berikut.

\section{a. Keteladanan}

Keterlaksanaan pendidikan karakter kewirausahaan di UPJ SMKN 2 Pengasih sangat didukung oleh keteladanan yang mencerminkan nilai-nilai karakter yang ditunjukkan oleh guru, karyawan, tukang maupun sesama siswa. Guru dan karyawan di UPJ TKKY memberi teladan yang ditunjukkan dalam perilaku dan sikap dalam mengajar praktik kayu maupun mengelola UPJ. Selama mereka bekarja, maka secara tidak langsung akan memberi teladan kepada siswa bagaimana cara merancang produk, membuat produk, memasarkan produk, dan sampai pada cara memuaskan pelanggan.

Tukang profesional yang bekerja di UPJ TKKY juga merupakan teladan bagi siswa dalam membuat suatu produk. Bagaimana cara tukang bekerja akan diamati oleh siswa-siswa. Selain keterampilan dan pengetahuan dalam bekerja, para siswa juga mengamati tentang sikap tukang-tukang dalam bekerja. Sikap kejujuran, tanggung jawab, semangat kerja pantang menyerah, ketelitian, kedisiplinan, dan kerja keras tukang tukang UPJ TKKY akan diteladani oleh para siswa yang terlibat di dalam kegiatan UPJ.

Siswa yang memiliki keterampilan tinggi dalam bidang praktik konstruksi kayu juga merupakan teladan bagi siswa lainnya dalam bekerja. Diantara siswa-siswa jurusan TKKY SMKN 2 Pengasih memang terdapat beberapa siswa yang memiliki keterampilan tinggi dan dilibatkan dalam kegiatan UPJ TKKY. Mereka itu biasanya para siswa yang dipersiapkan untuk mengikuti Lomba Kompetensi Siswa (LKS) baik tingkat propinsi maupun tingkat nasional. 


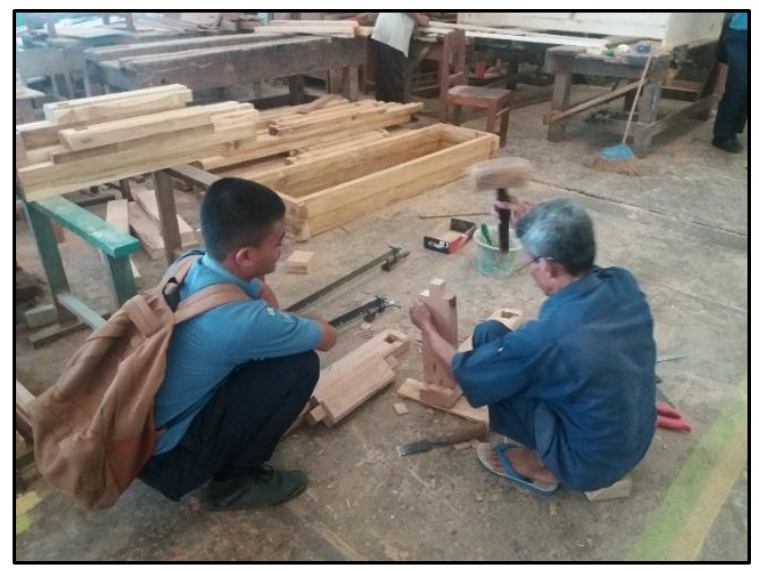

Gambar 1.Keteladanan dari Tukang UPJ TKKY

\section{b. Pembelajaran}

Pembelajaran karakter kewirausaha-an dalam UPJ TKKY dilakukan melalui berbagai kegiatan yang terbagi menjadi kegiatan pembelajaran kurikuler dan kokurikuler. Pendidikan karakter kewirausahaan melalui kegiatan kurikuler dilakukan pada saat pelajaran praktik mata pelajaran produktif dan pada saat ujian mata pelajaran produktif. Pelaksanaan mata pelajaran produktif praktik kayu dilakukan melalui kerja sama dengan UPJ berupa pembuatan meja $1 / 2$ biro, pembuatan bifet mini, pembuatan tangga kayu, pembuatan meja kursi siswa, dan pembuatan meja kursi guru. Sedangkan pada saat ujian praktik kayu juga bekerjasama dengan UPJ TKKYberupa pembuatan pembuatan daun pintu, daun jendela, kosen pintu dan kosen jendela. Pada pelajaran praktik dan ujian tersebut tidak hanya dinilai tentang pengetahuan dan keterampilan dalam pembuatan produk, tetapi juga tentang sikap dalam bekerja. Pada umumnya pelaksanaan mata pelajaran praktik dan ujian tersebut dilakukan secara berkelompok dengan anggota 2 siswa/kelompok.

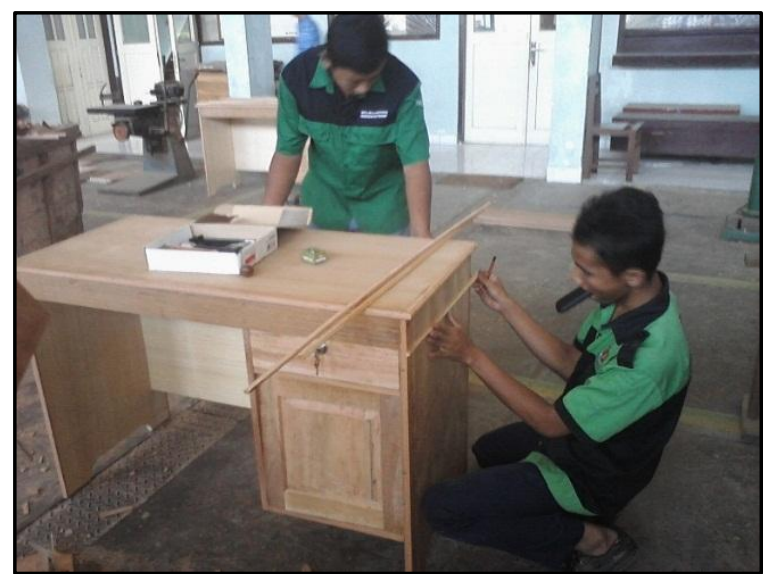

Gambar 2.Praktik Mata Pelajaran Produktif di UPJ TKKY

\section{c. Pemberdayaan dan Pembiasaan}

Pemberdayaan sebagai salah satu strategi pendidikan karakter kewirausahaan di UPJ TKKY telah dilakukan melalui pemberdayaan guru-guru, karyawan, dan peralatan 
untuk melangsungkan kegiatan produksi sekaligus sebagai upaya pendidikan karakter kekwirausahaan. Pemberdayaan tersebut sebagai tidak lanjut dari visi SMKN 2 Pengasih yaitu :

(a) Mengembangkan kompetensi siswa laki-laki dan perempuan melalui pendidikan formal di bidang ipteks.

(b) Menyiapkan peserta didik menjadi tenaga profesional, laki-laki dan perempuan yang berkarakter bangsa.

(c) Menyediakan layanan kepada masyarakat melalui Unit Produksi dan Jasa (UPJ) sebagai wahana berlatih wirausaha bagi peserta didik laki-laki dan perempuan

Sesuai dengan teori dari Berkowitz dalam Elkind \& Sweet (2004:1) "Effective character education is not adding a program or set of programs to a school. Rather it is a transformation of the culture and life of the school" maka kultur sekolah di lingkungan UPJ TKKY juga dibuat untuk mendukung pendidikan karakter kewirausahaan. Upaya penataan kultur sekolah di lingkungan UPJ TKKY tersebut antara lain dilakukan melalui:

(a) Rekruitmen tukang kayu profesional untuk mendukung keberlangsungan proses produksi.

(b) Penataan bengkel yang dibuat seperti dunia kerja.

(c) Pemasangan motto-motto yang mengandung pendidikan karakter kewirausahaan di lingkungan bengkel/UPJ TKKY.

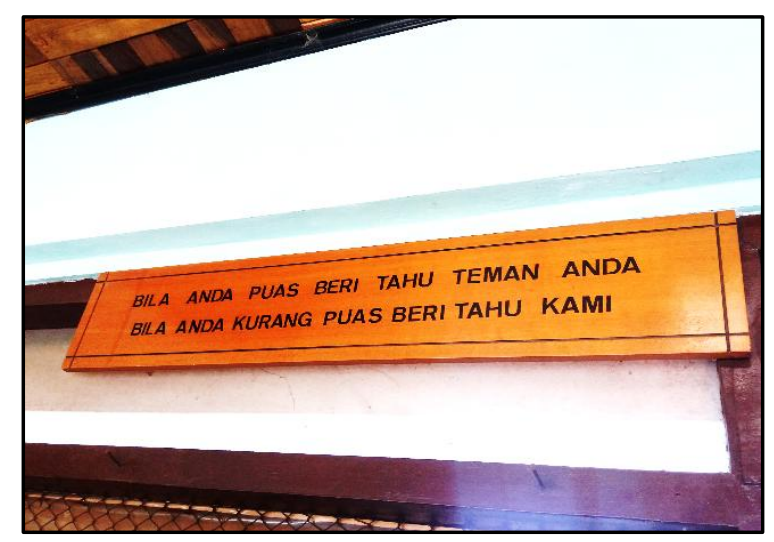

Gambar 3.Salah satu Motto di UPJ TKKY

\section{d. Penguatan}

Penguatan sebagai salah satu dari pendidikan pendidikan karakter kewirausahaan di UPJ TKKY telah dilakukan melalui beberapa kegiatan, antara lain: (a) pemanfaatan tukang profesional sebagai teladan pendidikan karkater, (b) perekrutan siswa-siswa sebagai tukang di UPJ TKKY, (c) pendatangan guru tamu dari dunia industri mebelair untuk memberikan pendidikan karakter kewirausahaan, dan (d) pemanfaatam hasil produksi UPJ TKKY untuk dipakai di SMKN 2 Pengasih seperti mejaguru, meja siswa, kursi guru, kursi siswa, pintu dan jendela. Melalui berbagai kegiatan penguatan tersebut diyakini akan dapat menumbuhkan karakter kewirausahaan bagi siswa program keahlian Teknik Konstruksi Kayu yang terlibat di dalam UPJ TKKY. 


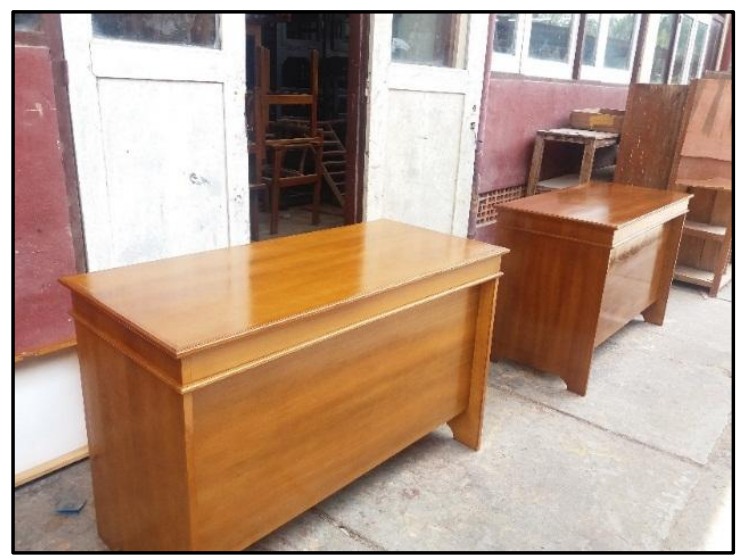

Gambar 4.Meja 1/2 biro hasil UPJ TKKY yang akan dipakai di SMKN 2 Pengasih

\section{e. Penilaian}

Strategi penilaian pendidikan karakter di UPJ TKKY dilakukan pada saat siswasiswa melakukan praktik mata pelajaran produktif maupun pada saat ujian. Melalui strategi penilaian diperoleh data tentang sikap siswa-siswa selama bekerja menyelesaikan job maupun sikap selama ujian. Salah satu sikap yang dinilai adalah sikap dalam menjalankan keselamatan kerja.

\section{Karakter kewirausahaan yang terkandung dalam pendidikan karakter kewirausahaan melalui UPJ TKK di SMKN 2 Pengasih}

Karakter kewirausahaan yang diutamakan dalam proses produksi UPJ TKKY baik melalui praktik mata pelajaran produktif, ujian mata pelajaran produktif maupun melalui proses produksi oleh tenaga UPJ seperti tabel berikut ini.

Tabel 1. Karakter Kewirausahaan yang Diutamakan di UPJ TKKY

\begin{tabular}{|c|c|c|c|c|}
\hline \multirow{2}{*}{ No } & \multirow{2}{*}{ Kegiatan UPJ } & \multicolumn{3}{|c|}{ Karakter Kewirausahaan yang Diutamakan } \\
\hline & & Pola Pikir & Pola Rasa & Pola Tindakan \\
\hline 1 & $\begin{array}{l}\text { Praktik Mata } \\
\text { Pelajaran produktif }\end{array}$ & $\begin{array}{l}\text { a. Kreatif } \\
\text { b. Inovatif } \\
\text { c. Realistis }\end{array}$ & $\begin{array}{l}\text { a. Berani } \\
\text { mengambil } \\
\text { risiko } \\
\text { b. Jujur } \\
\text { c. Tanggung } \\
\text { jawab } \\
\text { d. Rasa ingin tahu }\end{array}$ & $\begin{array}{l}\text { a. Kerja keras } \\
\text { b. Berorientasi } \\
\text { pada tindakan } \\
\text { c. Komunikatif }\end{array}$ \\
\hline 2 & $\begin{array}{l}\text { Ujian Mata } \\
\text { Pelajaran produktif }\end{array}$ & $\begin{array}{l}\text { a. Kreatif } \\
\text { b. Inovatif } \\
\text { c. Realistis }\end{array}$ & $\begin{array}{ll}\text { a. Tanggung } \\
\text { jawab } \\
\text { b. Pantang } \\
\text { menyerah } \\
\text { c. Mandiri }\end{array}$ & $\begin{array}{l}\text { a. Kerja keras } \\
\text { b. Kerja sama } \\
\text { c. Disiplin }\end{array}$ \\
\hline 3 & Produksi mebelair & $\begin{array}{l}\text { a. Kreatif } \\
\text { b. Realistis }\end{array}$ & $\begin{array}{l}\text { a. Jujur } \\
\text { b. Tanggung } \\
\text { jawab } \\
\text { c. Pantang }\end{array}$ & $\begin{array}{l}\text { a. Kerja keras } \\
\text { b. Komunikatif } \\
\text { c. Kerja sama }\end{array}$ \\
\hline
\end{tabular}

Model Pendidikan Karakter Kewirausahaan ..(Nuryadin Eko Raharjo) 


\begin{tabular}{|l|l|l|l|l|}
\hline & & $\begin{array}{l}\text { menyerah } \\
\text { d. Motivasi kuat } \\
\text { untuk sukses }\end{array}$ & \\
\hline
\end{tabular}

\section{Model pendidikan karakter kewirausahaan melalui unit produksi dan jasa di SMKN 2 Pengasih}

Berdasarkan data-data yang diperoleh selama penelitian ini dapat disusun model pendidikan karakter kewirausahaan yang dilakukan melalui UPJ TKKY di SMKN 2 Pengasih. Model tersebut mencakup proses pembelajaran yang dilakukan melalui kegiatan kurikuler dan melalui proses produksi UPJ TKKY. Berbagai strategi yang digunakan dalam pendidikan karakter tersebut mencakup: keteladanan, pembelajaran, pemberdayaan dan pembiasaan, penguatan serta penilaian.

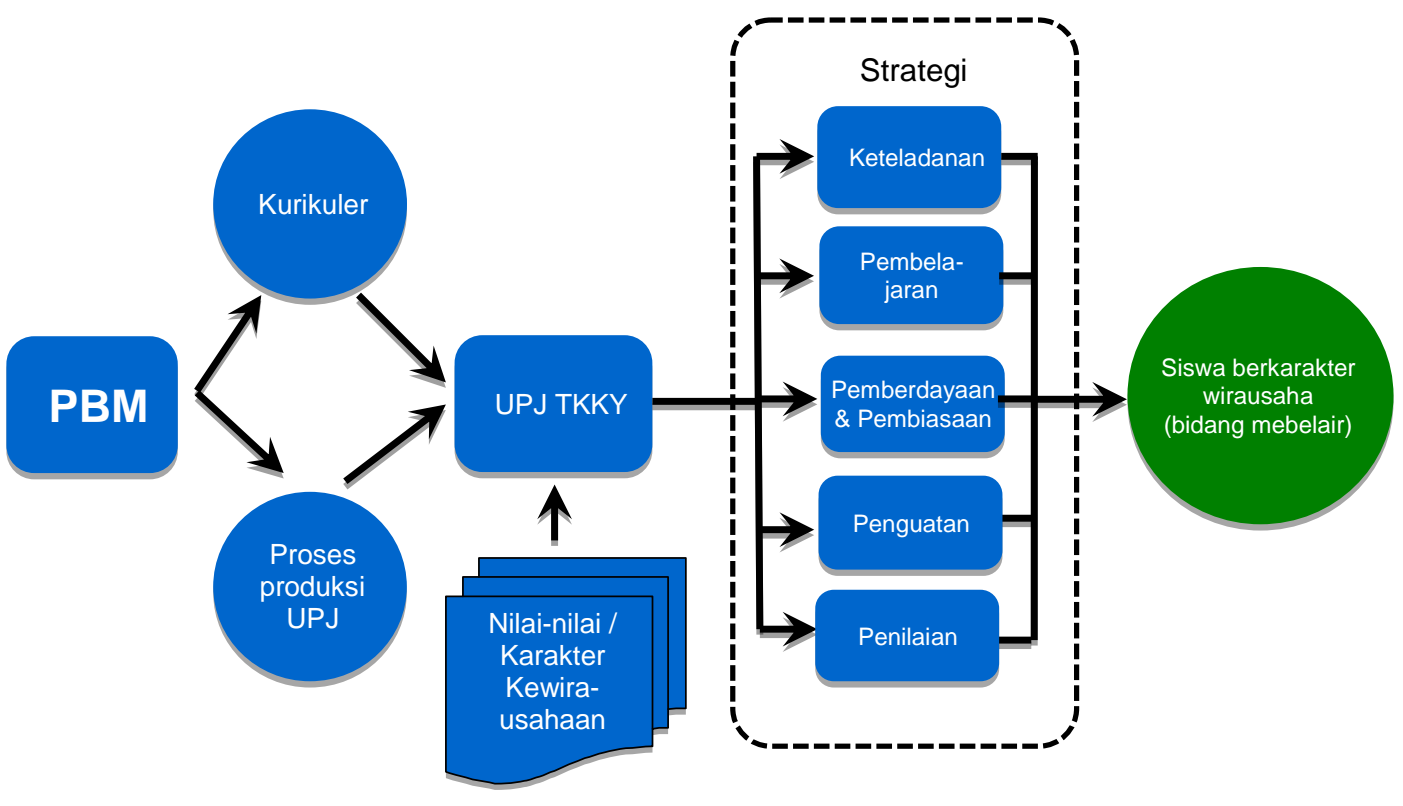

Gambar 5.Model Pendidikan Karakter Kewirausahaan melalui UPJ TKKY

Implementasi pendidikan karakter kewirausahaan melalui keteladanan di UPJ TKKY telah berhasil menarik perhatian para siswa, baik yang dilakukan oleh guru, karyawan, tukang professional, maupun oleh para siswa yang memiliki keterampilan yang telah memadai. Selain itu keberadaan guru tamu dari pihak dunia industri juga telah berhasil membuka wawasan siswa untuk mengimplementasikan pendidikan karakter kewirausahaan melalui kegiatan-kegiatan di UPJ TKKY. Strategi keteladanan melalui UPJ ini sesuai dengan konsep pendidikan among Ki Hajar Dewantara yang sarat akan nilai pendidikan karakter terutama pada point pertama sebagai berikut:

(1) Ing ngarsa sung tuladha, jika di depan memberi teladan: mengandung nilai keteladanan, pembimbingan dan pemanduan. 
(2) Ing madya mangun karsa, jika di tengah-tengah menyumbangkan gagasan: mengandung nilai kreativitas dan pengembangan gagasan serta dinamisasi pendidikan.

(3) Tut wuri handayani, jika dibelakang menjaga agar tujuan pendidikan dapat tercapai dan peserta didik diberi motivasi serta diberi dukungan psikologis untuk mencapai tujuan pendidikan: mengandung nilai memantau, melindungi, merawat, menjaga, memberikan penilaian dan saran perbaikan, sambil memberikan kebebasan untuk bernalar dan mengembangkan karakter peserta didik. (Samani \& Hariyanto, 2011:33).

Strategi pembelajaran dalam pendidikan karakter kewirausahaan melalui UPJ yang ditemukan dalam penelitian ini selaras dengan rancangan pendidikan kewirausahaan dari Kementerian Pendidikan Nasional pada Rembug Nasional tahun 2010 dimana pentahapan pelaksanaan pendidikan karakter kewirausahaan yang dimulai sejak pendidikan anak usia dini (PAUD) sampai pada perguruan tinggi (PT) dengan porsi antara pendidikan kewirausahaan dan pendidikan karakter yang tidak linier (Slamet PH, 2010:428).Pada tahap awal di tataran PAUD, pendidikan karakter lebih banyak proporsinya dibanding pendidikan kewirausahaan. Pada tataran PT porporsinya adalah kebalikan dari proporsi di PAUD. Di tingkatan SMK yang masuk pada pendidikan menengah, pada awalnya proporsi antara pendidikan kewirausahaan berimbang dengan pendidikan karakter. Untuk selanjutnya, menuju ke tingkat PT, proporsi pendidikan karakter semakin mengecil.

Implementasi pendidikan karakter kewirausahaan melalui UPJ dengan strategi pemberdayaan dan pembiasaan sesuai dengan teori dalam Desain Induk Pendidikan Karakter (Nuh, 2010:10) yang menjelaskan bahwa pendidikan karakter menanamkan kebiasaan (habituation) tentang hal mana yang baik sehingga peserta didik menjadi paham (kognitif) tentang mana yang benar dan salah, mampu merasakan (afektif) nilai yang baik dan biasa melakukannya (psikomotor).

Strategi penguatan dalam pendidikan karakter kewirausahaan melalui UPJ dalam penelitian ini juga sesuai dengan teori dari Nuh (2010:8) yang menjelaskan tentang pembentukan karakter melalui rekayasa faktor lingkungan (kultur sekolah) dapat dilakukan melalui strategi: (1) keteladanan, (2) intervensi, (3) pembiasaan yang dilakukan secara konsisten, dan (4) penguatan.

Implementasi strategi penilai dalam penelitian ini sebenarnya dapat menggunakan teori dari Ndraha (2005: 44) yang dapat memberikan kesimpulan/pertimbangan tentang pencapaian suatu indikator atau bahkan suatu nilai. Kesimpulan/pertimbangan tersebut dapat dinyatakan dalam pernyataan kualitatif dan memiliki makna terjadinya proses pembangunan karakter kewirausahaan yang meliputi: intensity, extensity, dan clarity. Penilaian dalam hal intensity merupakan penilaian dalam hal kedalaman karakter kewirausahaan pada penanamannya, apakah baru sekedar dilakukan atau sudah sampai dihayati. Penilaian dalam hal extensity menunjukkan seberapa luas kalangan yang merespon (nurut, niru, manut) penanaman karakter kewirausahaan. Penilaian dalam hal Clarity menunjukkan sedefinitif apa karakter kewirausahaan bagi warga sekolah. Karakter kewirausahaan yang disepakati oleh warga sekolah dapat ditentukan secara jelas. Kejelasan nilai-nilai ini ditentukan dalam bentuk filosofi, slogan, asumsi dasar, visi misi sekolah, serta prinsip-prinsip atau peraturan 
sekolah. Sekolah yang memiliki nilai-nilai budaya yang jelas dapat memberikan pengaruh nyata dan jelas kepada perilaku warga sekolahnya.

Dari penelitian ini diketahui bahwa secara umum pendidikan karakter kewirausahaan melalui UPJ TKKY pada ranah pola pikir mencakup: (1) kreatif, (2) inovatif, dan (3) realistis. Karakter kewirausahaan pada ranah pola rasa mencakup: (1) berani mengambil risiko, (2) jujur, (3) tanggung jawab, (4) rasa ingin tahu, (5) pantang menyerah, (6) mandiri, dan (7) motivasi kuat untuk sukses. Adapun ranah pola tindakan dalam karakter kewirausahaan mencakup: (1) kerja keras, (2) berorientasi pada tindakan, (3) komunikatif, (4) kerja sama, dan (5) disiplin.

Model pendidikan karakter kewirausahaan melalui UPJ yang ditemukan dalam penelitian ini dapat diterapkan pada sekolah lain (SMK) yang memiliki UPJ serta berkarakteristik sama dengan SMKN 2 pengasih. Untuk pengembangannya perlu di perbaiki struktur organisasi UPJ supaya tidak sentralistik kepada ketua UPJ saja, tetapi lebih tertata managemennya yang mengutamakan kewirausahaan.

\section{SIMPULAN}

(a) Strategi yang digunakan dalam pendidikan karakter kewirausahaan melalui UPJ TKKY di SMKN 2 Pengasih meliputi: keteladanan, pembelajaran, pemberdayaan, pembiasaan, penguatan, dan penilaian.

(b) Karakter kewirausahaan dalam ranah pola pikir (mindset)yang terkandung dalam pendidikan karakter kewirausahaan melalui UPJ TKKY di SMKN 2 Pengasih meliputi: (1) kreatif, (2) inovatif, dan (3) realistis.

(c) Karakter kewirausahaan dalam ranah pola rasa (heartset)yang terkandung dalam pendidikan karakter kewirausahaan melalui UPJ TKKY di SMKN 2 Pengasih meliputi: (1) berani mengambil risiko, (2) jujur, (3) tanggung jawab, (4) rasa ingin tahu, (5) pantang menyerah, (6) mandiri, dan (7) motivasi kuat untuk sukses.

(d) Karakter kewirausahaan dalam ranah pola tindakan (actionset)yang terkandung dalam pendidikan karakter kewirausahaan melalui UPJ TKKY di SMKN 2 Pengasih meliputi: (1) kerja keras, (2) berorientasi pada tindakan, (3) komunikatif, (4) kerja sama, dan (5) disiplin.

(e) Model pendidikan karakter kewirausahaan melalui unit produksi dan jasa di SMKN 2 Pengasih dilakukan melalui kegiatan kurikuler dan kegiatan proses produksi UPJ dengan menggunakan strategi: keteladanan, pembelajaran, pemberdayaan, pembiasaan, penguatan, dan penilaian.

\section{DAFTAR RUJUKAN}

Akbar, A.I. (2009). Pendidikan Berbasis Hard Skill dan Soft Skill. Diakses pada tanggal $15 \quad$ Februari 2012 dari http://mkadministrasinegara.blogspot.com/2009/06/pendidikan-berbasis-hard-skill-dansoft.html.

Biro Pusat Statistik. (2014). Berita Resmi Statistik No. 85/11/Th.XVII tanggal 5 November 2014. Diakses dari http://www.bps.go.id/getfile.php?news=1149 pada tanggal 20 November 2014. 
Carsrud, A.L \& Brannback, M. E. (2007). Entrepreneurship. London:Greenwood Press.

Casson, M. (2003). The Entrepreneur: an Economic Theory. $2^{\text {nd }}$ edition. Northampton: Edward Elgar.

Dharma, S. (2007). Manajemen Unit Produksi/Jasa sebagai Sumber Belajar Siswa dan Penggalian Dana Pendidikan Persekolahan. Jakarta: Direktorat Tenaga Kependidikan Dirjen PMPTK.

Dharma, S. (2010). Kewirausahaan : Materi Pelatihan Penguatan Kepala Sekolah. Jakarta: Direktorat Tenaga Kependidikan Dirjen PMPTK.

Elkind, D.H. \& Sweet, F. (2004). How to do Character Educaiion. Diakses pada tanggal 5 Februari 2015 dari http://www.goodcharacter.com/Article_4.html

Goleman, D. (2006) Kecerdasan Emosional: Mengapa EI lebih penting dari IQ. Jakarta: Gramedia Pustaka Utama

ILO. (2005). Modul 1: Apakah Usaha dan Kewirausahaan Itu? Turin, Italy: International Training Centre, ILO.

Lickona, T., Schaps, E., \& Lewis, c., (2007). CEP's Eleven Principles of Effective Character Education. Diakses pada tanggal 15 Februari 2012 dari http://www.character.org/uploads/PDFs/Eleven_Principles.pdf.

Ndraha, Taliziduhu. (2005). Teori Budaya Organisasi. Jakarta: Rineka Cipta.

Nuh, M. (2009). Kebijakan Pendidikan Nasional Dorong Kewirausahaan. Diakses pada tanggal 4 Januari 2011dari http://www.mandikdasmen. depdiknas.go.id/web/ beritaumum/ 336.html.

Nuh, M. (2010). Desain Induk Pendidikan Karakter Kementerian Pendidikan Nasional. Jakarta: Kementrian Pendidikan Nasional.

Ramly, M. dkk (2011), Pedoman Pelaksanaan Pendidikan Karakter. Jakarta: Pusat Kurikulum dan Perbukuan, Balitbang, Kemendiknas.

Samani, M. \& Hariyanto. (2011). Konsep dan Model Pendidikan Karakter. Bandung: Rosdakarya.

Simpeh, K.N. (2011). Entrepreneurship theories and Empirical research. European Journal of Business and Management. Vol 3, No.6, 2011

Slamet PH. (2010). Implementasi Pendidikan Karakter Kerja dalam Pendidikan Kejuruan. dalam Darmiyati Zuchdi (2010). Pendidikan Karakter dalam Perspektif Teori dan Praktik (Hal. 406-431). Yogyakarta: UNY Press.

Suyanto. (2007). SMK Solusi yang Tepat Mengatasi Pengangguran Terdidik. Diakses pada tanggal $15 \quad$ Oktober 2011dari http://www.bipnewsroom.info/index.php?\&newsid=24658\&_link=loadnews.php

Suyanto. (2009). Pemerintah Tingkatkan Pendirian SMK untuk Atasi Pengangguran. Jakarta: Tempo interaktif. Diakses pada tanggal 15 Oktober 2011dari 
http://www.tempo.co/read/news/2009/05/13/079176082/Pemerintah-TingkatkanPendirian-SMK-untuk-Atasi-Pengangguran.

Usman, H. dkk (2010). Pengembangan Pendidikan Kewirausahaan. Jakarta: Pusat Kurikulum, Badan Penelitian dan Pengembangan, Kementerian Pendidikan Nasional. 